\title{
A STUDY ON ECOTECT APPLICATION OF LOCAL CLIMATE AT A RESIDENTIAL AREA IN CHUNCHEON, KOREA
}

\author{
Qian WU, Hyun-Kil JO \\ Kangwon National University, Chuncheon, Republic of Korea \\ Submitted 18 Mar. 2014; accepted 07 Oct. 2014
}

\begin{abstract}
The local climate data were investigated at a residential area in Chuncheon from May to October in 2013. In addition, the simulations were carried out by the Autodesk Ecotect Analysis tool. Site A had the lowest temperature in summer. The best building orientation was south by east $157.5^{\circ}$. Based on the photosynthetically active radiation (PAR) values day-neutral species should be planted around sites $\mathrm{C}$ and $\mathrm{E}$, shade-tolerant species around site $\mathrm{D}$ and helioplous species around sites A and B. In addition, site A is the most comfortable place in the residential area with a predicted mean vote (PMV) value around 0 . It was found that there were four main aspects to be considered for the residential designs which were building height, land cover, planting design and building orientation. Moreover, the results showed that local climate and shading conditions should be of great concern in design or improvement of residential areas.
\end{abstract}

Keywords: local climate, air temperature, Ecotect, thermal comfort, landscape management.

\section{Introduction}

Urban microclimate is significantly affected by the solar radiation and shading conditions, since solar radiation affects temperature (Andreou 2014). There are not enough green spaces and cool sinks in downtown area, and hampered airflow in the canyons which decrease the escape ability of the emitted infrared radiation in the atmosphere (Andreou 2014). In addition, geometry parameters such as building height and building orientation determine solar access and shading conditions. Hence, they play an important role in the thermal comfort of outdoor spaces and also the energy performance of buildings (Jouri, Miljana 2012). It has also been reported that urban geometry is much more crucial at the microscope than thermal behavior, materials and the albedo (Andreou 2014). Moreover, it is of high importance whether the research of microclimate can provide the design guidelines to the residential area at the beginning of the design (Andreou 2014). Relationship between solar access issues with orientation and latitude have been considered in the past (Paramita, Koerniawan 2013). The effects of geometry and orientation on solar access and shading conditions for different latitudes have been examined by some researchers (Bourbia, Awbi 2004). In addition, some studies reported the urban density, orientation and solar access, in an effort to investigate urban design options (Van Esch et al. 2012).

In this study, simulations were carried out using the Autodesk Ecotect Analysis tool (2011, US) which has high capability to be successfully used for the analysis of the building orientation, shading conditions, solar access, PAR value and thermal comfort. Ecotect is an environmental analysis tool which can simulate building performance right in the design stage. It has a wide array of detailed analysis functions with a visual and interactive display that can make the analysis results be found directly in the analytical picture (Yang et al. 2014). Therefore, Ecotect was selected as the analysis software of this study. The geometrical parameters of physical model and study area location were the variables imported into the software. The effect of geometry and shading conditions, building orientation and meteorological condition were previously considered in many studies (Andreou 2014), while there were four new points in the present study. First, combination of the measurement data and Ecotect simulations to analyze the thermal comfort in a residential area. Second, comprehensive analysis of the local climate weather data in Chuncheon. Third, building orientation, shading conditions, solar access, PAR values and thermal comfort were taken into consideration in residential area design.

Corresponding author: Hyun-Kil Jo

E-mail: jhk@kangwon.ac.kr 
Fourth, a new connection between ecological theory and landscape design was developed. All the measurement data and Ecotect simulations were combined to analyze the microclimatic changes and assess the problems in residential area design.

The study area was a residential area in Chuncheon which is the capital of Kangwon province, South Korea. The lowest measured temperature was $-27.9^{\circ} \mathrm{C}$ (February 6, 1969), and the highest was $36.8^{\circ} \mathrm{C}$ (Aug 5, 2012) (Korea Meteorological Administration 2011). Figure 1 shows the exact location of the residential area and Figure 2 shows the layouts of five measurement sites, which include 25 buildings that cover 8.12 ha. The area was located in the east part of downtown area in Chuncheon, consisting of four apartments, Chonggu, Booyoung, Jinheung, and Doosan. There were five measurement sites in the study area, each with $30 \mathrm{~m}$ diameters representing the same size area $\left(706.9 \mathrm{~m}^{2}\right)$. The five measurement sites in the central part of each apartment and the central area in the whole study area were selected according to the different green cover percentages.

\section{Methods}

\subsection{Data sources}

The data used in this study were air temperature (Ta), relative humidity $(\mathrm{RH})$, solar radiation (SR) and wind speed (V) in a residential area during the growing period, spanning from May to October in 2013. The field surveys involved microclimatic monitoring with the use of the portable weather measurement equipments. During the summer, the surface temperature (Ts) was measured for the asphalt, concrete, grass, soil and cream color wall in the study area.

At each measurement site, the portable weather data logging equipments were used for recording Ta and RH (Thermo-hygrometer TH-100, Japan), SR (LI-250 Light Meter, Japan), V (Anemometer TA 45, UK) and Ts (K-type Thermometer SK-1110, Japan). All the microclimatic factors such as Ta, RH, SR and V were measured on the height of $1.5 \mathrm{~m}$ away from the ground. The surveys took place every month during the growing period, but the surface temperature was just measured from June to August which is summer in Chuncheon. Each point was monitored 3 times $\left(5^{\text {th }}, 15^{\text {th }}\right.$ and $\left.25^{\text {th }}\right)$ every month in summer and once $\left(15^{\text {th }}\right)$ every month in spring and fall, for 24 hours a day at $3 \mathrm{~h}$ intervals.

\subsection{Simulations}

After creating 3D model of the study area confirmed by the geometrical parameters from field measurement, the location information was analyzed by Ecotect using the tool bar for the necessary functions (Fig. 3). The longitude and latitude were $127.8^{\circ} \mathrm{E}$ and $37.9^{\circ} \mathrm{N}$, respectively. Finally, the shading and thermal comfort were calculated and visualized. Also, solar radiation was simulated over any period as long as the information of the area was input.

\section{Results}

\subsection{Building information and land cover characteristics}

There were 25 buildings in the study area including four management offices with just one floor. The building floors and heights were listed in Table 1. The biggest height

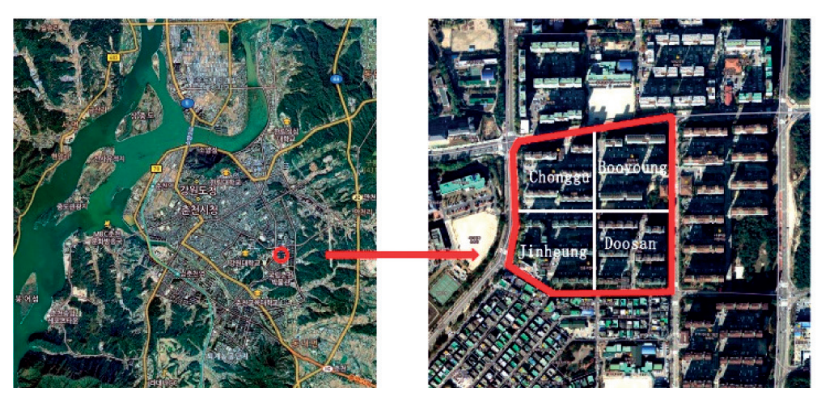

Fig. 1. Local study area in Chuncheon. The red line indicates the boundary of the study area including four apartments; Chonggu, Booyoung, Jinheung and Doosan

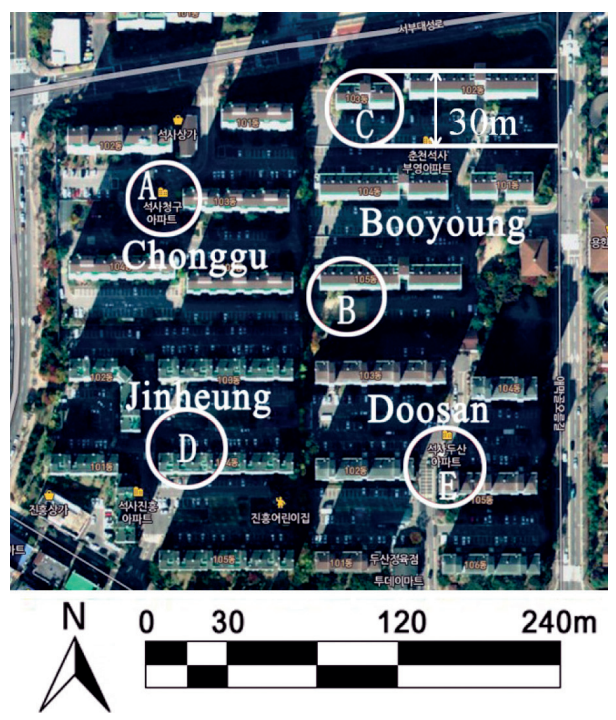

Fig. 2. Layouts of five measurement sites. All the measurement sites are equal-size circles with $30 \mathrm{~m}$ in diameter
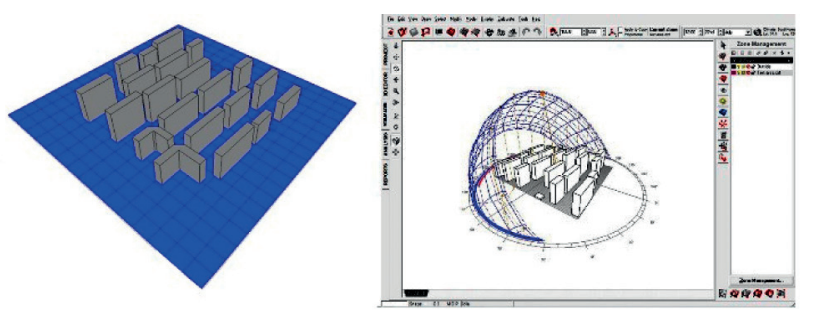

Fig. 3. The 3D model of the study area and the interface of Autodesk Ecotect Analysis tool (2011, US) 
difference of the buildings was $21 \mathrm{~m}$ except the management offices. Table 2 summarizes the land cover and surface characteristics of each measurement site. It can be found that site $\mathrm{A}$ had the highest green ratio (43\%) and site $\mathrm{C}$ had the lowest.

Table 1. Buildings information in the study area

\begin{tabular}{lcccccccc}
\hline Building floor & 19 & 18 & 16 & 15 & 14 & 13 & 12 & 1 \\
\hline $\begin{array}{l}\text { Number of } \\
\text { buildings }\end{array}$ & 1 & 4 & 2 & 7 & 3 & 3 & 1 & 4 \\
$\begin{array}{l}\text { Height (m) } \\
57\end{array}$ & 54 & 48 & 45 & 42 & 39 & 36 & 4 \\
\hline
\end{tabular}

\subsection{Local climatic measure results}

Figure $4 \mathrm{a}$ shows the Ta measure results from 6 am to 6 pm during May to October. Site $\mathrm{C}$ had the highest average Ta reaching $27.9{ }^{\circ} \mathrm{C}$ which was $1{ }^{\circ} \mathrm{C}$ higher than site A which was the lowest Ta $\left(26.9^{\circ} \mathrm{C}\right)$ at $3 \mathrm{pm}$. Comparing the $\mathrm{Ta}$ in site $\mathrm{A}$ and $\mathrm{C}$ with the same time that is the Ta difference ranged from $0.7-1{ }^{\circ} \mathrm{C}$ from 6 am to $6 \mathrm{pm}$ and the biggest difference was at $3 \mathrm{pm}$. The Ta in site $\mathrm{B}$ was slightly lower than site $\mathrm{C}$ and higher than site $\mathrm{D}$, with the differences was $0.2-0.4{ }^{\circ} \mathrm{C}$ and $0.2-0.6{ }^{\circ} \mathrm{C}$, respectively. No significant differences were observed between sites D and E. Generally, site E was slightly lower than site D. Apparently, site $\mathrm{C}$ had the highest Ta, followed by site B, D, E and A.

The $\mathrm{RH}$ change trend was presented in Figure $4 \mathrm{~b}$. Not surprisingly, five sites showed similar general trend. Comparing the $\mathrm{RH}$ in the five sites at the same time, site A had the highest RH (62.3\%) and site C was the lowest (59.3\%). Site E was found to exhibit lower $\mathrm{RH}$ $(0.3-1.7 \%)$ than site $\mathrm{A}$ followed by sites $\mathrm{D}$ and $\mathrm{B}$. In addition, there was a slight difference between sites $B$ and D $(0.2-0.6 \%)$.

Figure $4 \mathrm{c}$ shows the wind speed differences in five sites. Comparing V in day time, the value of site A was higher than other areas and the average value was $0.57 \mathrm{~m} / \mathrm{s}$ in site A. There is no significant difference among other four sites. Moreover, the obvious change trend was not found in $\mathrm{V}$ in the study area.
The T-test had been used to compare the weather measurement data and simulation. All the parameters' $P$ values were greater than 0.05 , which means there was no significant difference between measurement data and simulation. Therefore, Ecotect simulation was feasible in this study.
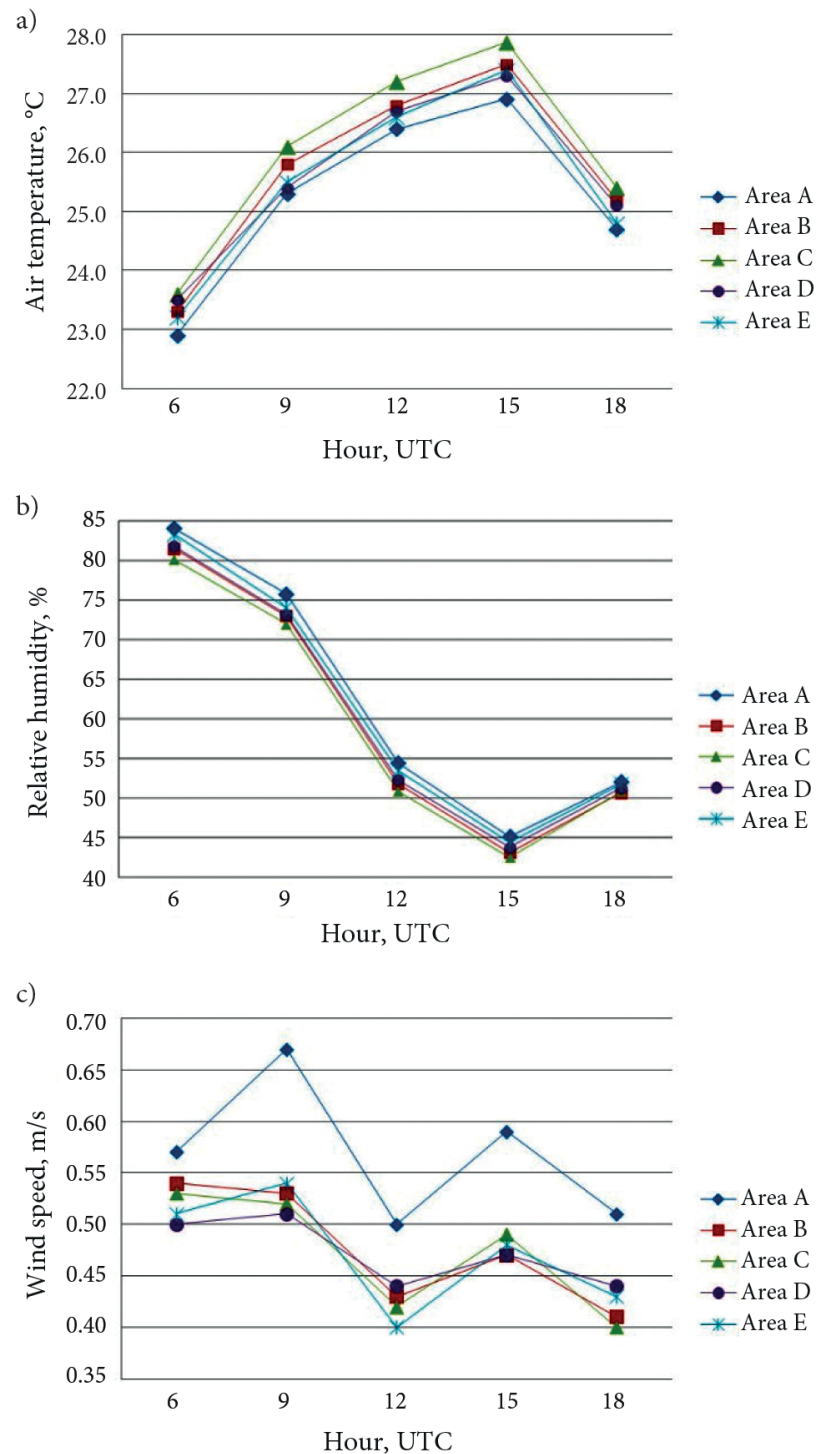

Fig. 4. Comparison of weather measurements:

a) Air temperature; b) Relative humidity; c) Wind speed

Table 2. Summary of land cover and surface characteristics of each measurement site

\begin{tabular}{|c|c|c|c|c|c|c|c|c|c|c|}
\hline \multirow{3}{*}{ Site } & \multirow{3}{*}{$\begin{array}{l}\text { Area } \\
\left(\mathrm{m}^{2}\right)\end{array}$} & \multicolumn{8}{|c|}{ Horizontal surface } & \multirow{3}{*}{$\begin{array}{c}\text { Vertical surface } \\
\text { Wall }\left(\mathrm{m}^{2}\right)\end{array}$} \\
\hline & & \multirow{2}{*}{ Building (\%) } & \multicolumn{5}{|c|}{ Greenspace (\%) } & \multirow{2}{*}{$\begin{array}{c}\text { Concrete } \\
(\%)\end{array}$} & \multirow{2}{*}{$\begin{array}{c}\text { Asphalt } \\
(\%)\end{array}$} & \\
\hline & & & Trees & Shrub & Grass & Soil & Total & & & \\
\hline A & 706.9 & 38 & 32 & 15 & 24 & 3 & 43 & 12 & 7 & 1267.4 \\
\hline B & 706.9 & 49 & 8 & 5 & 6 & 10 & 22 & 15 & 14 & 1335.6 \\
\hline $\mathrm{C}$ & 706.9 & 51 & 5 & 4 & 7 & 9 & 18 & 19 & 12 & 1604.4 \\
\hline $\mathrm{D}$ & 706.9 & 49 & 10 & 7 & 7 & 8 & 25 & 15 & 11 & 1375.2 \\
\hline $\mathrm{E}$ & 706.9 & 48 & 29 & 6 & 25 & 3 & 34 & 12 & 6 & 1623.6 \\
\hline
\end{tabular}




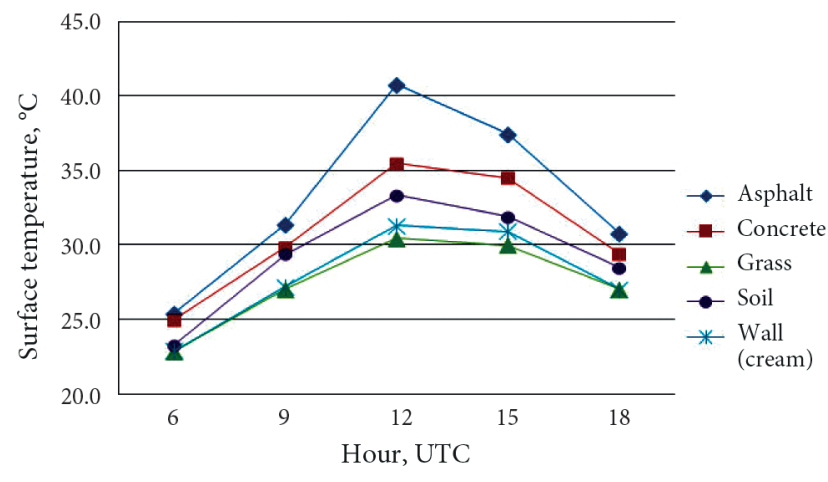

Fig. 5. Surface temperatures of five different surface types in summer time

\subsection{Surface types and temperature}

Figure 5 shows the five main types of surfaces in the study area including the horizontal and vertical surfaces. The day-time surface temperatures were presented. There were five types of surface in the study area which were asphalt, concrete, grass, soil and cream color wall. The highest surface temperatures were recorded at the mid-day temperature of the pavement in the exposed ground (reaching a maximum $40.9{ }^{\circ} \mathrm{C}$ absorbed in asphalt ground surface) and grass surface temperature was $30.4^{\circ} \mathrm{C}$, which its surface temperature started to rise from 9 am to $3 \mathrm{pm}$. It can be found that asphalt had the highest values and grass had the lowest values. Not surprisingly, site A had the highest green ratio and lowest hard surface including concrete and asphalt showed the lowest Ta in summer and site C was the opposite.

\subsection{Shading conditions and PAR value}

The shading analysis was carried out using the shading range tool. Figure 6 presents the shadow range of the whole study area from May to October. The violet red color rectangles were the building plans which rounded by the simulation of diurnal sun orbit. All the semitransparent grey shades were arranged by the Ecotect tool. Apparently, October had the most shade during the six months. Comparing the shade amount in five sites, site $\mathrm{D}$ had the most shade and site $\mathrm{C}$ had the least. It can be found that site A had more shade than sites $\mathrm{E}$ and $\mathrm{B}$.

The average daily PAR was shown in Figure 7 and Figure 8 (summer time). The Insolation Analysis tool can simulate the PAR value from $0.40-5.40 \mathrm{MJ} / \mathrm{m}^{2} \mathrm{~d}$. Figure 7 used eleven colors and 5.148 visible nodes showed the PAR values in the whole study area. It can be found that there was no 5.40 and $4.90 \mathrm{MJ} / \mathrm{m}^{2} \mathrm{~d}$ value in study area from May to October and also in summer time (June, July and August). The highest value was $4.4 \mathrm{MJ} / \mathrm{m}^{2} \mathrm{~d}$ in the west, southwest and east side and lowest value was $0.40 \mathrm{MJ} / \mathrm{m}^{2} \mathrm{~d}$ which is building area. The value was about $0.90-1.90 \mathrm{MJ} / \mathrm{m}^{2} \mathrm{~d}$ in site $\mathrm{D}$ which was the lowest in the five sites. Sites A's and B's value ranged from $2.40-3.40 \mathrm{MJ} / \mathrm{m}^{2} \mathrm{~d}$. Another two sites $\mathrm{C}$ and $\mathrm{E}$ had the values between $2.40-2.90 \mathrm{MJ} / \mathrm{m}^{2} \mathrm{~d}$.
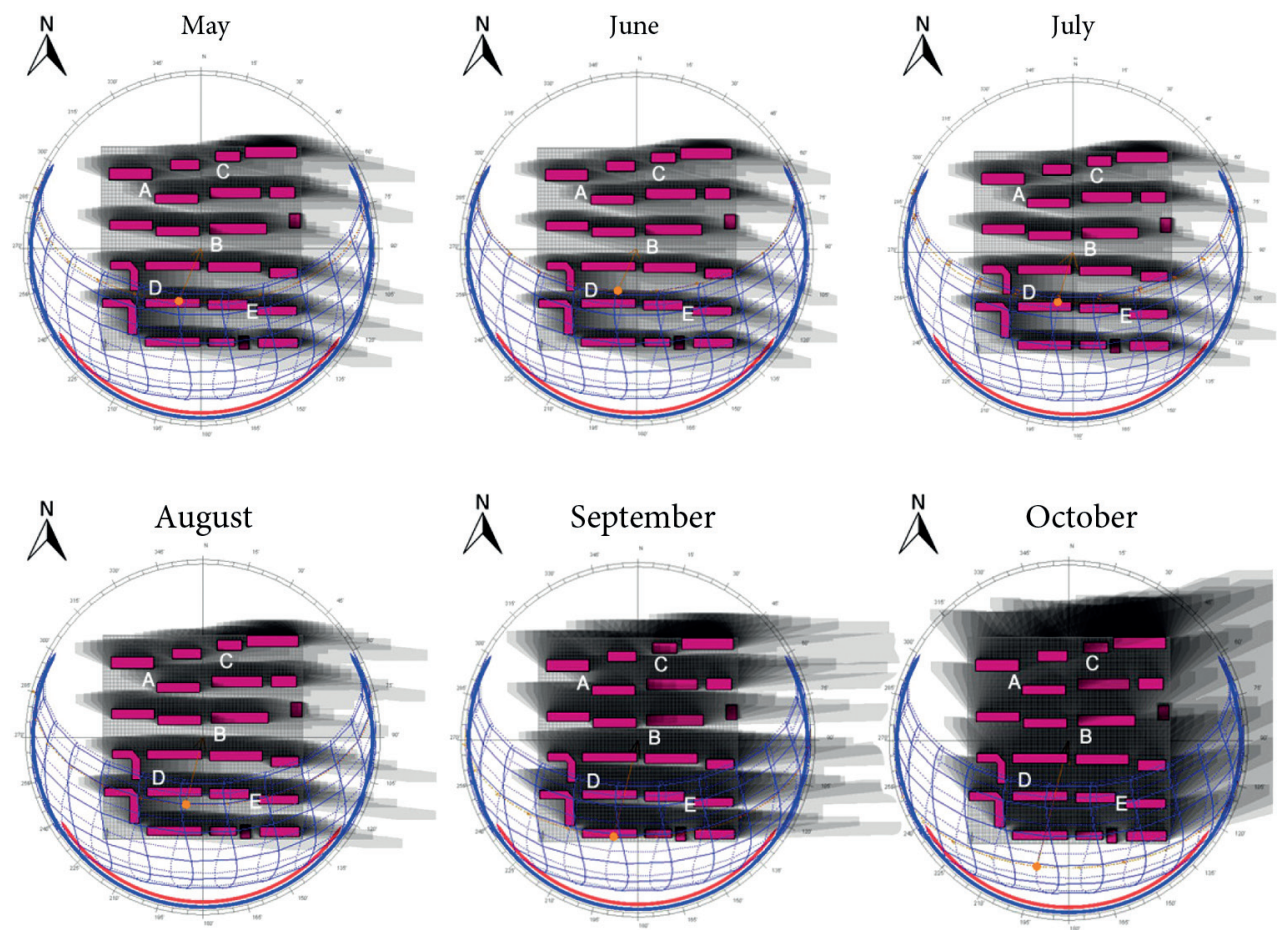

Fig. 6. Shading conditions simulations from May to October in the study area. The rectangles are the buildings' master plan and there are some semitransparent shadows around them 


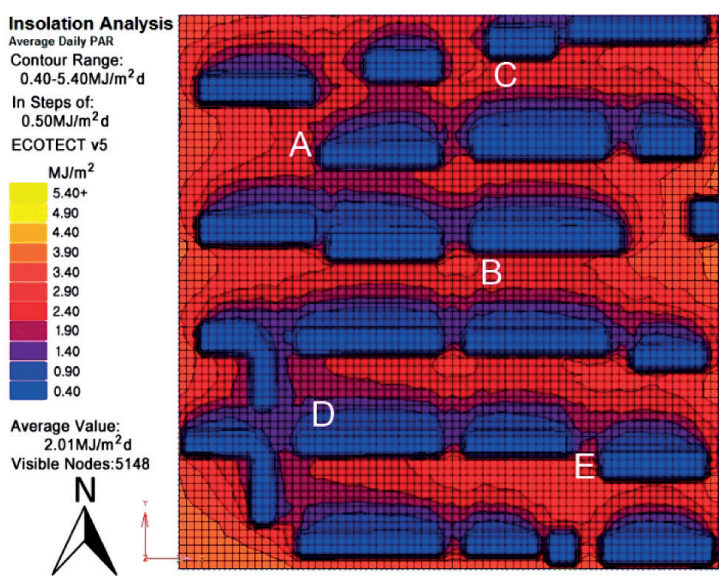

Fig. 7. PAR analysis from May to October
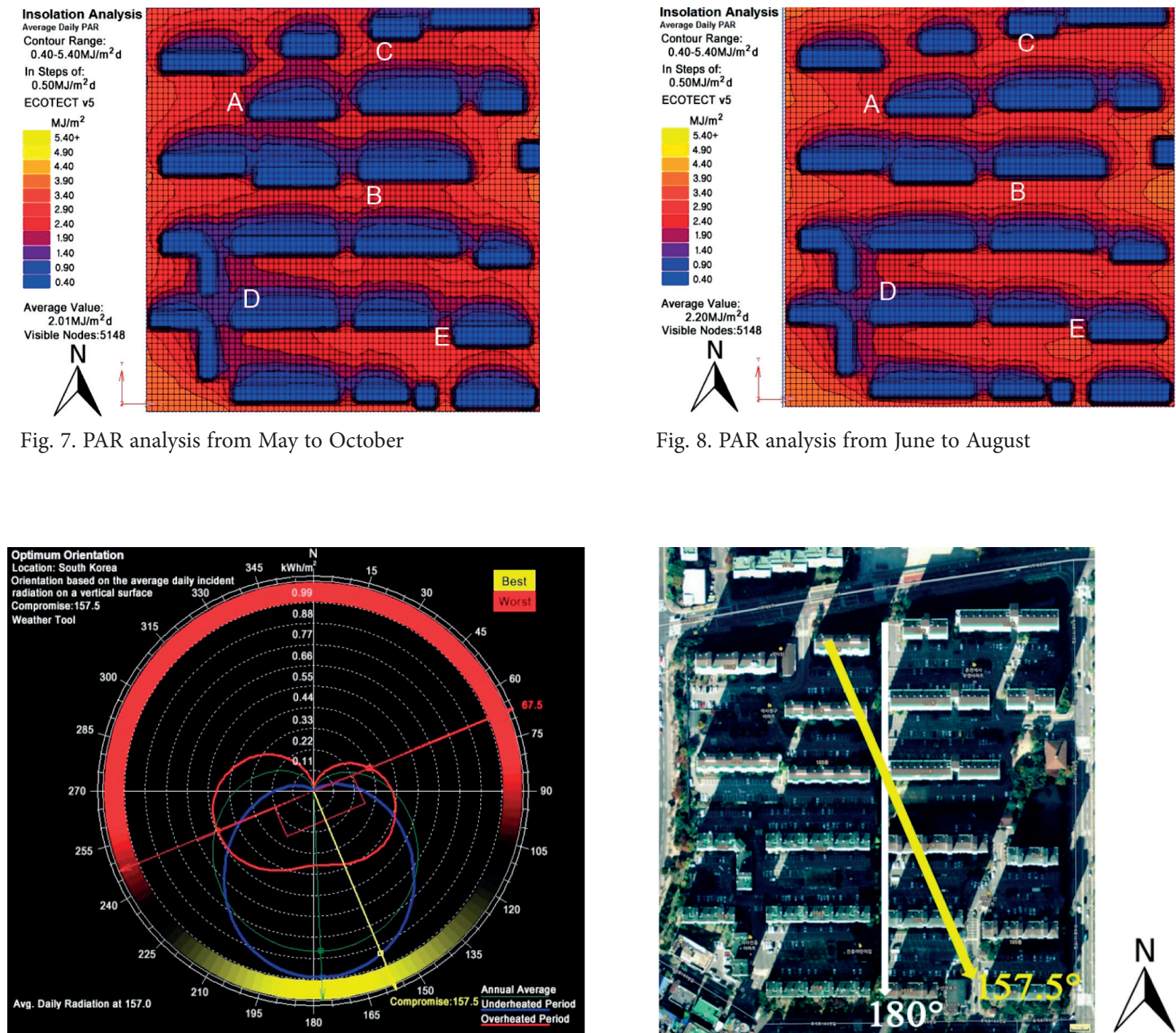

Fig. 8. PAR analysis from June to August

. Analysis of best building orientation. The yellow arrow shows the best building orientation $\left(157.5^{\circ}\right)$ and the white arrow was the present building orientation (south) in the study area

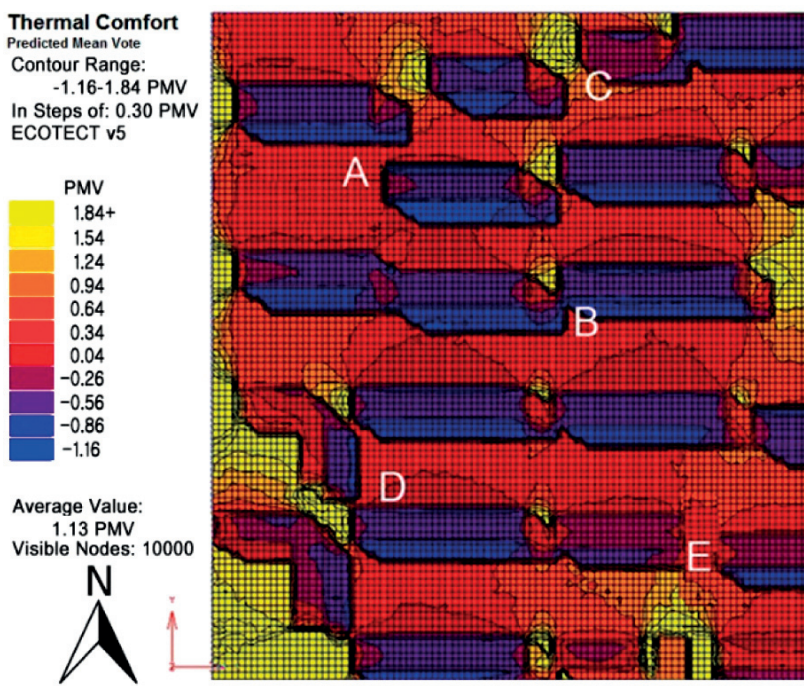

Fig. 10. Analysis of predicted mean vote in the study area in June

\subsection{Best building orientation}

According to the best building orientation analysis from the Autodesk Ecotect Analysis tool (Fig. 9), the green line was annual average range, the blue line was under heated range and the red line was overheated range. The yellow line was the best building orientation range. The white arrows in right side picture showed the primary building orientation which needs to be modified and the yellow arrows showed the best building orientation. In order to avoid the under heated and overheated situation, $157.5^{\circ}$ (south by east $22.5^{\circ}$ ) was the best building orientation in study area and north by east $67.5^{\circ}$ was the worst.

\subsection{Thermal comfort}

Figures 10, 11 and 12 show the PMV in summer (June, July and August) carried out by thermal comfort 


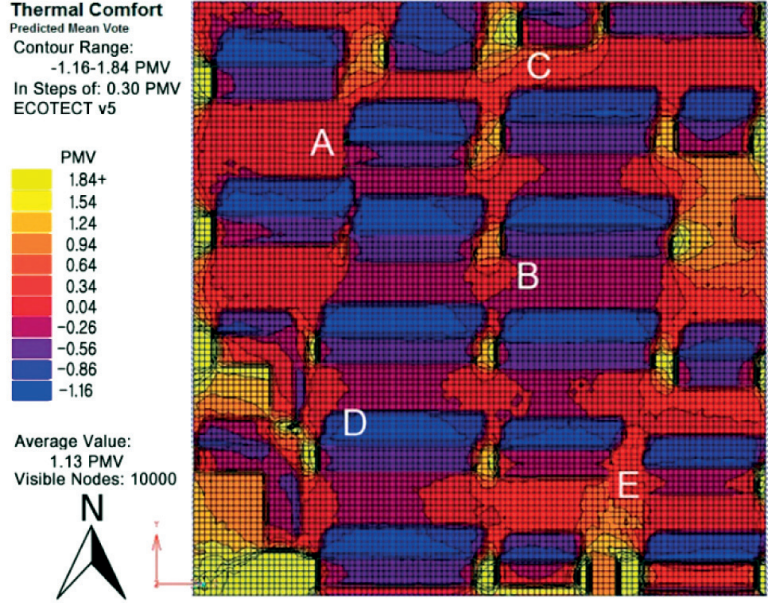

Fig. 11. Analysis of predicted mean vote in the study area in July

analysis tool. There were eleven colors and 10,000 visible nodes showing the PMV values. The PMV value in the study area ranged from -1.16 to 1.84 and the average value was 1.13 . It can be found that most of the study area had the PMV value between 0.04 and 0.34 . Moreover, the value was over 1.84 just in the southwest side and a little in east side in the study area. Site A's and E's average PMV was closest to $0(0.34)$ and site C was the highest $(0.64-1.24)$. When refer to the PMV around site $\mathrm{D}$ was between -0.86 and 0.34 . Site $\mathrm{B}$ was ranged from -0.86 to 0.04 .

\section{Discussion}

Site $\mathrm{C}$ was located at the parking lot with the low percentages of green cover (Table 2) and used more pavements compared with other sites, which is one of the reasons that it showed the highest temperature. Not surprisingly, site A proved to be the coldest site and had highest $\mathrm{RH}$ since it had the highest green ratio.

Although all the measurement data was recorded in the sunny days, there were many rainy days in July, which may had influenced the results of average $\mathrm{RH}$ data at five measurement sites. It is well known that evapotranspiration emissions of water vapour conduce to the humidity in urban area (Gup-yu et al. 2013). Therefore, site A, which had the highest green ratio showed more evapotranspiration and had the highest $\mathrm{RH}$, and the lowest Ta value, while site $\mathrm{C}$ had the opposite trend. In addition, the RH diurnal variation curves show the same changing trend which was because of Ta, $\mathrm{V}$ and evapotranspiration.

The dominant wind was from northwest in the study area in summer (Korea Meteorological Administration 2011). But there were 21 high-rise buildings in the study area which could reduce the wind speed and changed the wind direction. Apparently, there was no high building in the west of site A to stop the airflow which resulted in it

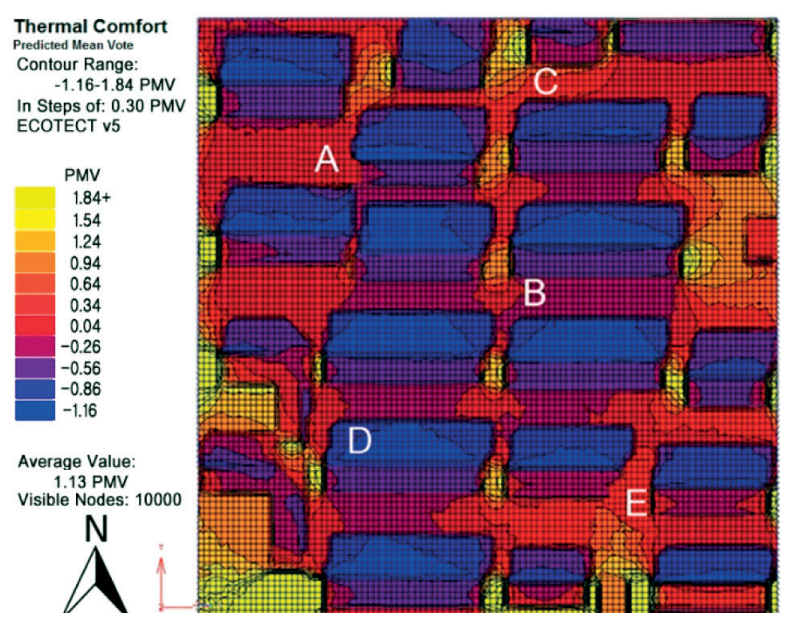

Fig. 12. Analysis of predicted mean vote in the study area in August

being the site with the highest wind speed which also one of the reasons that site $\mathrm{A}$ is the coolest space among all. However, the buildings around sites B, C, D and E almost had the similar height and same direction which could stop the wind flow in this area.

Another element influencing both air temperature and human thermal comfort is the radiant temperature which comes from surface (Limor et al. 2009). Materials used in the vertical and horizontal surfaces play a very important role in the urban thermal balance (Santamouris et al. 2011). Many studies have been carried out to analyze the optical and thermal characteristics of materials as well as their impact on the surface temperature (Hassan et al. 2014). It can be found that sites $A$ and $E$ had less asphalt surface than sites $B$ and $C$ that is one of the reasons they were cooler in summer.

Both vegetation and shading have the potential to reduce air temperature and cool the atmosphere (Bonan 2000). High shading percentage has a significant impact on the pedestrian thermal comfort as well as on the temperature (Capeluto et al. 2005). In other words, if the building orientation is $157.5^{\circ}$ in the study area, all the building will face the wind blowing direction, which can be one of the cooling effects in hot summer. In the study area, all the buildings orientations were south which is not good for the wind flow in summer. If the building orientations could be changed to $157.5^{\circ}$, it would be easier to absorb the heat in winter and have appropriate ventilation in summer which can save the fuel and energy more efficiently.

Sites A and E had more shading time during summer, which is one of the reasons they were cooler than other sites. It can be found that sites B and D had the similar green ratio, but their temperatures were different because site $\mathrm{D}$ had more shade than site $\mathrm{B}$, resulting in about $0.2-0.6{ }^{\circ} \mathrm{C}$ temperature difference between the two sites. 
PAR designates the spectral range of solar radiation from 400 to 700 nanometers that belong to visible light, which can be absorbed by photosynthetic organisms to use in the process of photosynthesis (Andrew et al. 2006). Therefore, PAR can be one of the parameter to consider in planting design. The PAR range was from $0.40-5.40 \mathrm{MJ} / \mathrm{m}^{2} \mathrm{~d}$ and the area which the value was lower than $1.9 \mathrm{MJ} / \mathrm{m}^{2} \mathrm{~d}$ need to plant shade-tolerant species, $1.90-2.90 \mathrm{MJ} / \mathrm{m}^{2} \mathrm{~d}$ is better to plant the day-neutral species and over $2.90 \mathrm{MJ} / \mathrm{m}^{2} \mathrm{~d}$ is good for the heliophilous species. Therefore, it properly plants the shade-tolerant species around site $\mathrm{D}$, the day-neutral species around sites $\mathrm{C}$ and $\mathrm{E}$ and heliophilous species around sites A and B.

Best building orientation is the most fundamental and generally, most easily addressed aspect of passive solar design which should use the ecology and energy saving technology to design (Morrissey et al. 2011). Appropriate design should consider key building parameters such as building orientation, plan proportion and building shape (Aksoy, Inalli 2006). Therefore, all the buildings orientation could be changed to south by east $22.5^{\circ}$; it would be more effective to make the cooling effect in the study area in summer.

One of the most widely used indexes is PMV, which predicts the mean thermal response of a large population of people (Ruey-Lung, Shiu-Ya 2011). There are seven scales of PMV $(+3=$ hot, $+2=$ warm, $+1=$ slightly warm, $0=$ neutral, $-1=$ slightly cool, $-2=$ cool, $-3=$ cold $)$ (RueyLung, Shiu-Ya 2011). PMV has been included in the International Organization for Standardization ISO standard (PVM ISO 7730: 2005). Originally developed as an indoor thermal comfort index, PMV has also been commonly adopted in outdoor thermal comfort studies in which large groups of people were being surveyed (Cheng et al. 2012). Sites A's and E's PMV was most close to 0 (0.34), which means that sites $\mathrm{A}$ and $\mathrm{E}$ were most comfortable. In addition, site $\mathrm{C}$ was so hot in summer and the PMV value is largest (0.64-1.24). Even according to Ta, site E was cooler than sites B and D. But when refer to the PMV around site $B$ is between -0.86 to 0.04 , so site $B$ has the higher comfort level.

\section{Conclusions}

1. This study was based on time series analysis of Ta, RH, $\mathrm{SR}, \mathrm{V}$ and Ts that were carried out at five measurement sites in a residential area in Chuncheon. The monthly variations of the four factors were determined, showing that five measurement sites had different microclimate changes because of the land cover differences. Site $\mathrm{C}$ showed the highest mean diurnal air temperature $\left(27.9^{\circ} \mathrm{C}\right)$ at $3 \mathrm{pm}$ because of the surroundings and site A was the coldest in summer because of the lowest Ta. In addition, hereby results address the relevance of the three factors in the microclimate.
2. The results of the study show that: A) Sites A and $\mathrm{E}$ had more shading time during summer and site $\mathrm{D}$ had more shade than site $\mathrm{B}$ which resulted in Ta to be $0.2-0.6{ }^{\circ} \mathrm{C}$ higher in site $\mathrm{B}$ than site $\mathrm{D}$ in summer; B) Shade-tolerant species may be useful for site D because the PAR value was lower than $1.90 \mathrm{MJ} / \mathrm{m}^{2} \mathrm{~d}$ which is good for shade-tolerant species to grow. In addition, day-neutral species should be planted in sites $\mathrm{C}$ and $\mathrm{E}$ because the PAR value was between $1.9-2.9 \mathrm{MJ} / \mathrm{m}^{2} \mathrm{~d}$ which is good for the day-neutral plants to grow. Heliophilous species can be planted around sites A and B according to the PAR value which is higher than $2.9 \mathrm{MJ} / \mathrm{m}^{2} \mathrm{~d}$; C) The best building orientation was south by east $22.5^{\circ}$ in the study area.

3. Based on the weather measurements data and simulations from the Autodesk Ecotect Analysis tool, the study introduced the suggestions for the modification design of this area. Firstly, after analyzing the difference between the five sites, it is not difficult to find that the sites which had green cover percentage between 30-40\% were cooler that the other ones. It can be boldly conceived that if the green ratio is $30 \%-40 \%$ in the whole area uniformly, the air temperature will be lower and the comfort level will be higher. Secondly, there should be more shade-tolerant species around site $\mathrm{D}$, while more day-neutral species should be added at sites $\mathrm{C}$ and $\mathrm{E}$ and heliophilous species can be planted around sites A and B. Meanwhile, changing the planting design by the PAR distribution diagram will be an applicable way to change the microclimate in the study area. Finally, the biggest difference height between adjacent buildings was $6 \mathrm{~m}$ around site A, resulting in faster airflow than other sites. On the contrary, all the buildings were almost the same height around site $C$, so airflow was so slow which had bad influences such as decrease the Ta because of the airflow obstruction. If the buildings have different heights and all the building orientation is perpendicular to the dominant wind direction, the best airflow condition may be possible.

4. Rapid economical development all over the world and the contemporary problems of energy insufficiency and waste. Therefore, ecological landscape management and architect design and sustainable development have become the most important factors of designers. Hence, the ecological design assistive tools such as Autodesk Ecotect Analysis tool will become the new research direction and will be widely used for various regional. Using such tools can improve the building design but also from the reducing energy consumption of buildings. The solar radiation analysis, solar orbit simulation and thermal comfort analysis can be displayed visually and specifically by Ecotect. Meanwhile, urban designer could make more considerations to various ecological methods in the begin stage of design the whole process of landscape management by analyzing them. In addition, it is significant to create an environmental-friendly, comfortable and energy saving 
living environment by analyzing the initial design of the residential area, educational area, industrial area, etc.

\section{Acknowledgements}

The authors would like to express their gratitude to the Laboratory of Urban Ecosystem Planning in Kangwon National University for the financial support.

\section{References}

Aksoy, U. T.; Inalli, M. 2006. Impacts of some building passive design parameters on heating demand for a cold region, Building and Environment 41: 1742-1754. http://dx.doi.org/10.1016/j.buildenv.2005.07.011

Andreou, E. 2014. The effect of urban layout, street geometry and orientation on shading conditions in urban canyons in the Mediterranean, Renewable Energy 63: 587-596. http://dx.doi.org/10.1016/j.renene.2013.09.051

Andrew, O.; Susan, C.; Grimmond, B.; Hans-Peter, S.; Craig, A. W. 2006. Local-scale heterogeneity of photosynthetically active radiation (PAR), absorbed PAR and net radiation as a function of topography, sky conditions and leaf area index, Remote Sensing of Environment 103: 324-337. http://dx.doi.org/10.1016/j.rse.2005.09.021

Bonan, G. B. 2000. The microclimates of a suburban Colorado (USA) landscape and implications for planning and design, Landscape and Urban Planning 49: 97-114. http://dx.doi.org/10.1016/S0169-2046(00)00071-2

Bourbia, F.; Awbi, H. B. 2004. Building cluster and shading in urban canyon for hot dry climate part 2: shading simulations, Renewable Energy 29: 291-301. http://dx.doi.org/10.1016/S0960-1481(03)00171-X

Capeluto, I. G.; Yezioro, A.; Bleiberg, T.; Shaviv, E. 2005. From computer models to simple design tools: solar rights in the design of urban streets, in the 9th International Building Performance Simulation Association (IBPSA), 15-18 August 2005, Montreal, Canada, 131-138.

Cheng, V.; Ng, E.; Chan, C.; Givoni, B. 2012. Outdoor thermal comfort in sub-tropical climate: a longitudinal study based in Hong Kong, International Journal of Biometeorology 56: 43-56. http://dx.doi.org/10.1007/s00484-010-0396-z

Gup-yu, Q.; Hong-yong, L.; Qing-tao, Z.; Wan, C.; Xiao-jian, L.; Xiang-ze, L. 2013. Effects of evapotranspiration on mitigation of urban temperature by vegetation and urban agriculture, Journal of Integrative Agriculture 12: 1307-1315. http://dx.doi.org/10.1016/S2095-3119(13)60543-2
Hassan, R.; Essam, A.; Stephen, S. 2014. On the colours and properties of building surface materials to mitigate urban heat islands in highly productive solar regions, Building and Environment 72: 162-172. http://dx.doi.org/10.1016/j.buildenv.2013.11.005

Jouri, K.; Miljana, H. 2012. Solar energy as a design parameter in urban planning, Energy Procedia 30: 1143-1152. http://dx.doi.org/10.1016/j.egypro.2012.11.127

Korea Meteorological Administration (KMA) [online]. 2011 [cited 2 May 2011]. Available from Internet: http://www. kma.go.kr/weather/climate/extreme_daily.jsp?type $=$ max_ temp\&mm $=13 \& \mathrm{x}=30 \& \mathrm{y}=8$

Limor, S. B.; David, P.; Evyatar, E. 2009. The cooling efficiency of urban landscape strategies in a hot dry climate, Landscape and Urban Planning 92: 179-186. http://dx.doi.org/10.1016/j.landurbplan.2009.04.005

Morrissey, J.; Moore, T.; Horne, R. E. 2011. Affordable passive solar design in a temperate climate: an experiment in residential building orientation, Renewable Energy 36: 568-577. http://dx.doi.org/10.1016/j.renene.2010.08.013

Paramita, B.; Koerniawan, M. D. 2013. Solar envelope assessment in tropical region building case study: vertical settlement in bandung, Indonesia, Procedia Environmental Science 17: 757-766. http://dx.doi.org/10.1016/j.proenv.2013.02.093

PMV ISO 7730: 2005. Ergonomics of the thermal environmentAnalytical determination and interpretation of thermal comfort using calculation of the PMV and PPD indices and local thermal comfort criteria. $52 \mathrm{p}$.

Ruey-Lung, H.; Shiu-Ya, S. 2011. Building envelope regulations on thermal comfort in glass facade buildings and energysaving potential for PMV-based comfort control, Building and Environment 46: 824-834. http://dx.doi.org/10.1016/j.buildenv.2010.10.009

Santamouris, M.; Synnefa, A.; Karlessi, T. 2011. Using advanced cool materials in the urban built environment to mitigate heat islands and improve thermal comfort conditions, Solar Energy 85: 3085-3102. http://dx.doi.org/10.1016/j.solener.2010.12.023

Van Esch, M. M. E.; Looman, R. H. J.; De Bruin-Hordijk, G. J. 2012. The effects of urban and building design parameters on solar access to the urban canyon and the potential for direct passive solar heating strategies, Energy and Buildings 47: 189-200. http://dx.doi.org/10.1016/j.enbuild.2011.11.042

Yang, L.; He, B.-J.; Ye, M. 2014. Application research of ECOTECT in residential estate planning, Energy and Buildings 72: 195-202. http://dx.doi.org/10.1016/j.enbuild.2013.12.040

Qian WU is currently carrying out her PhD at the Laboratory of Urban Ecosystem Planning in Kangwon National University. She graduated from college of Landscape Architecture of Northeast Forestry University (NEFU) in China and received her MSc in NEFU in 2012. Research interests: landscape architecture, urban ecosystem planning and greenspace planning.

Hyun-Kil JO received his PhD in University of Arizona in 1993. He was the vice-president of Korean Society of Environment and Ecology (2003-2005) and president of Ecological Landscape Association in the Korean Institute of Landscape Architecture (2003-2005). He is an editorial board of Landscape and Ecological Engineering (2005-present). He is currently a Prof. and Dean of College of Forest and Environmental Sciences, Kangwon National University. He is involved in scientific research for more than 25 years. His research interests are focused on ecological landscape architecture, urban ecosystem planning and greenspace planning. 